\title{
Spices and garbage two keys to healthy life
}

\section{Rempah dan sampah dua kunci menuju hidup sehat}

\author{
Anis Sholihah, Yuni Aulia Agustin, Nada Kutsuma Vacha, M. Alfan Yusuf \\ Departemen Agroteknologi, Fakultas Pertanian, Universitas Islam Malang \\ JL. MT.Haryono 193 Malang, 65144, Indonesia
}

\begin{abstract}
ARTICLE INFO
Received: 2020-12-17

Revised: 2021-02-26

Accepted: 2021-05-12

\section{Keywords:}

Chairs, Healthy drinks, Plastic waste, Spices

\section{ABSTRACT}

Indonesia is rich in various kinds of spices and its benefits are no doubt, Wadeng Sidayu Gresik Village has the potential for abundant spices but has not been used optimally, especially the COVID-19 pandemic, this healthy drink is one of the solutions to increase the body's immunity. Making healthy drinks from spices is expected to change the people's mindset towards a healthy lifestyle supported by a healthy, clean and free environment from waste and pollution, Ngoro Mojokerjo Village is a large industrial center in East Java so that plastic waste is very troubling because from time to time increased. The effort to reduce plastic waste is by using it as a chair at home. The two spice and waste activities in the two villages went through several stages; the first stage was conducting the survey, the second stage was applying for a permit to the local village head, the third stage was collecting spices and plastic waste and the fourth stage was training in making drinks, socializing the use of waste and making chairs from plastic waste. The results of the activity were that technology for making and healthy drink products, technology and chair products from plastic waste, and public awareness not littering increased by $61 \%$.
\end{abstract}

(C)2021 Published by University of Merdeka Malang. This is an open access article distributed under the CC BY-SA 4.0 license (https://creativecommons.org/licenses/by-sa/4.0/)

How to cite: Sholihah, A., Agustin, Y. A., Vacha, N. K., \& Yusuf, M. A. (2021). Spices and garbage two keys to healthy life. Abdimas: Jurnal Pengabdian Masyarakat Universitas Merdeka Malang, 6(4), 565-574.

https://doi.org/10.26905/abdimas.v6i4.5172

\section{PENDAHULUAN}

Rempah-rempah adalah bahan alami yang sudah lama digunakan dalam kehidupan sehari-hari. Rempah-rempah sering dimanfaatkan sebagai bumbu dapur dan peningkat cita rasa masakan. Rempahrempah memiliki bagian tumbuhan yang bersifat aromatik dan antioksidan alami. Salah satu contohnya adalah jahe yang menyimpan kandungan senyawa antioksidan yaitu Nortraselogenin dan Metil ester. Selain jahe, rempah-rempah lainnya yang memiliki banyak manfaat adalah kunyit. Tanaman kunyit ini memiliki banyak manfaat dalam bidang kesehatan. Sebagai contoh, kunyit dapat digunakan untuk penyakit asam lambung, menurunkan LDL, meredakan nyeri menstruasi, dan menyembuhkan luka. Zat aktif penting yang dimiliki oleh tanaman ini bernama kurkumin. Kurkuminoid ialah salah satu senyawa 
ABDIMAS: Jurnal Pengabdian Masyarakat Universitas Merdeka Malang Volume 6, No. 4, November 2021: 565-574

pembawa warna kuning pada kunyit yang bermanfaat dalam penurunan kolesterol, kolagogum, antibakteri, antihepatotoksik hingga antiinflamasi. Tak hanya kurkuminoid, senyawa I-turmeron yang ditemukan dalam rimpang temu lawak dapat dimanfaatkan sebagai obat beragam penyakit. Banyak penelitian yang telah membuktikan kegunaan kurkuminoid sebagai obat herbal terutama sebagai antihepatotoksik dan antikolesterol, serta obat sebagai terapi dalam pengobatan tumor dan kanker. Penghambatan pertumbuhan sel kanker dipengaruhi oleh adanya zat fenolik. Zat fenolik tersebut memiliki aktivitas antimutagenik yang mempengaruhi mutasi DNA dalam sel kanker. Penghambatan pertumbuhan berbagai jenis kanker seperti Ca paru, Ca payudara, dan Ca usus ditekan oleh kandungan senyawa dalam jenis tanaman family Zingiberaceae ini (Sari, 2016).

Pendayagunaan berbagai jenis tanaman rempah dalam bidang kuliner sudah sangat umum (Duke, 2002). Selain sebagai minuman, tanaman-tamanan tersebut juga dimanfaatkan sebagai obat herbal, zat penambahan dalam produk kecantikan hingga sebagai agen antibakteri. Seiring dengan meningkatnya kesadaran manusia terhadap pentingnya kesehatan, saat ini mulai muncul dan digencarkan kembali terkait pentingnya kesehatan berbasis tanaman.

Menurut Nuraida \& Hariyadi (2001), jamu dapat diolah menjadi minuman herbal fungsional jika tak meninggalkan karakteristik sensorinya sehingga minuman tersebut dapat memberikan keuntungan bagi masyarakat luas. Contoh minuman-minuman tersebut diantaranya adalah beras kencur, sari temu lawak, sari jahe, kunyit asam dan susu telor madu jahe. Dewasa ini, minuman herbal tersebut sudah kalah popularitas dengan banyak munculnya minuman kesehatan yang hadir dalam bentuk suplemen yang berasal dari bahan kimia dan pengawet.

Termasuk dalam daftar salah satu negara penghasil rempah terbesar di dunia, Indonesia merupakan salah satu negara penghasil rempah-rempah yang sangat beragam. Variasi hasil rempah-rempah tersebut menjadi ciri khas Indonesia yang tak terpisahkan dari sejarah bangsa Indonesia. Desa Wadeng, Kecamatan Sidayu, Kabupaten Gresik merupakan salah satu contoh daerah penghasil rempah-rempah yang relatif banyak, namun belum termanfaatkan secara optimal karena keterbatasan masyarakat akan teknologi pasca panen seperti pembuatan minuman sehat untuk meningkatkan imunitas tubuh terutama dalam periode pandemi COVID-19 yang terjadi saat ini. Memberikan pengetahuan kepada masyarakat akan pentingnya minuman sehat dari rempah-rempah hasil produk pertanian di daerah mereka untuk kesehatan, memberikan teknologi pengolahan minuman sehat dan menambah pendapatan masyarakat dengan menjual produk minuman sehat tersebut, menjadi tujuan peneliti dalam melakukan kegiatan ini.

Minuman sehat dan imunitas tubuh yang tinggi akan mudah dicapai apabila didukung oleh lingkungan yang bersih dan bebas dari sampah polusi. Sampah plastik adalah satu faktor yang berperan dalam perusakan lingkungan dan menjadi tugas seluruh masyarakat untuk melestarikan lingkungan hidup di mana mereka tinggal. Ketergantungan masyarakat Indonesia terhadap plastik sangat tinggi. Hal tersebut dikarenakan masyarakat hanya menginginkan kepraktisan saja agar barang-barang yang dibawanya tidak tercecer dengan dimasukkan ke dalam kantong plastik. Sayangnya, sampak plastik bersifat anorganik yang sulit terurai. Sampah plastik memerlukan waktu bertahun-tahun agar terurai secara sempurna. Tanpa disadari, sampah plastik dapat berubah menjadi polutan yang dapat mengancam 
kelestarian lingkungan. Setiap tahunnya, sebanyak 1,3 miliar ton dihasilkan di seluruh kota di dunia. Pada tahun 2025, World Bank menduga bahwa jumlah sampah plastik akan terus bertambah hingga 2,2 miliar ton per tahunnya. Laporan lainnya menyebutkan bahwa jumlah limbah plastik Jepang menyentuh angka 10 juta ton per tahun (Nishino et al., 2003). Pertambahan tersebut sejalan dengan bertambahnya jumlah penduduk di seluruh dunia. Semakin banyak jumlah penduduk suatu negara, maka semakin banyak pula limbah yang akan dihasilkan. Menurut data statistik, setiap orangnya membutuhkan kurang lebih $100 \mathrm{~kg}$ per tahunnya dalam penggunaan plastik dalam kehidupan mereka (Williams \& Slaney, 2007).

Badan Pusat Statistik Indonesia tahun 2018 menyatakan bahwa Indonesia menghasilkan sampah plastik sebanyak 64 juta ton per tahun dengan rincian sebesar 3,2 juta ton adalah sampah plastik laut dan sisanya adalah sampah lingkungan yakni sebanyak 10 miliar ton atau setara dengan 85.000 kantong plastik. Jumlah fantastis tersebut, mengantarkan Indonesia menduduki peringkat dua setelah Tiongkok sebagai negara pencemar sampah plastik terbesar di dunia. Peringkat tersebut bukanlah peringkat yang patut dibanggakan, karena sampah plastik berperan dalam pencemaran kehidupan laut dan mempengaruhi keseimbangan ekosistem di lautan (Novena, 2020).

Desa Ngoro merupakan salah satu kecamatan di Kabupaten Mojokerto, Jawa Timur, Indonesia. Kecamatan ini ialah salah satu kawasan industri di daerah Mojokerto. Salah satu area industri di wilayah Kabupaten Mojokerto ialah Ngoro Industrial Park (NIP). NIP ini terletak di wilayah antara Mojosari dan Watukosek. Mata pencaharian masyarakat Ngoro utamanya petani namun sebagian banyak yang beralih profesi sebagai buruh pabrik, mengingat Ngoro masuk dalam kawasan industri. Penduduk Desa Ngoro merupakan penduduk yang kesadaran membuang sampah pada tempatnya sangat rendah. Hal ini dibuktikan dengan terlihatnya sampah plastik yang berserakan dan sangat mengganggu pemandangan dan kesehatan. Berdasarkan latar belakang tersebut, maka tim pengabdi bertujuan untuk memberikan penyuluhan kepada masyarakat tentang urgensi membuang sampah pada tempatnya. Tak hanya itu, tim pengabdi juga memberikan edukasi teknologi terkait pemanfaatan sampah plastik agar menjadi barang yang lebih berguna sebagai kursi kecil perabot rumah tangga yang dapat menambah pendapatan masyarakat pada masa pandemi COVID-19.

\section{METODE}

Kegiatan pengabdian masyarakat ini dilakukan di dua desa; (1) Desa Wadeng Kecamatan Sidayu Kabupaten Gresik, dan (2) Desa Ngoro kecamatan Ngoro Kabupaten Mojokerto dimana keduanya termasuk dalam Provinsi Jawa Timur. Perekonomian utama dari Desa Wadeng Gresik adalah industri pupuk dan dolomite. Perekonomian desa ini banyak disumbangkan dari berbagai sektor, di antaranya adalah sektor UKM, pertanian, perdagangan, peternakan hingga melalui bidang kuliner. Salah satu contoh produk pertaniannya ialah rempah-rempah yang melimpah namun belum mendapat sentuhan teknologi pasca panen sehingga nilai jualnya rendah. Adanya pengetahuan teknologi dalam pembuatan minuman sehat diharapkan dapat meningkatkan pendapatan masyarakat setempat. Hasil rempahrempah dapat dimanfaatkan secara optimal sehingga berpengaruh dalam peningkatan imun masyarakat terutama pada masa pandemi COVID sekarang. 
ABDIMAS: Jurnal Pengabdian Masyarakat Universitas Merdeka Malang Volume 6, No. 4, November 2021: 565-574

Berbeda dengan Desa Wadeng, Desa Ngoro di Mojokerto dikenal sebagai area industri dengan sampah plastik yang sangat melimpah. Di samping hal tersebut, kesadaran membuang sampah pada tempatnya masih sangat rendah sehingga edukasi terkait urgensi membuang sampah pada tempatnya dan pengolahan sampah menjadi barang yang lebih bermanfaat sangat diperlukan.

\section{Pembuatan minuman sehat dari rempah-rempah}

Kegiatan pembuatan minuman sehat dari rempah-rempah ini dilaksanakan di Desa Wadeng Kecamatan Sidayu Kabupaten Gresik dengan beberapa penduduk selanjutnya hasil dari minuman sehat dibagikan kepada masyarakat (perangkat desa, pelapak dan pembeli di pasar di wilayah Desa Wadeng). Kegiatan ini berlangsung beberapa tahapan. Tahap pertama adalah survei lokasi pembagian minuman sehat dengan tujuan mendapatkan informasi yang tepat membagikan minuman sehat tersebut. Dari hasil survei diputuskan perangkat desa, pelapak dan para pembeli di Pasar Desa Wadeng. Tahap kedua adalah penyuluhan pentingnya minuman sehat dengan peserta penduduk Desa Wadeng bertempat di Balai Desa Wadeng. Penyuluhan pentingnya pemanfaatan rempah-rempah sebagai minuman sehat ditujukan untuk memberikan pengetahuan kepada masyarakat akan besarnya manfaat rempah-rempah sebagai minuman sehat meningkatkan imun tubuh.

Tahap ketiga adalah pembuatan minuman sehat dengan terlebih dahulu menyiapkan alat dan bahan-bahan yang akan digunakan untuk pelaksanaan pembuatan minuman sehat. Alat-alat yang dipersiapkan meliputi, panci, pisau, telenan, botol plastik, saringan, pengaduk, stiker, dan gunting. Bahan yang dipersiapkan meliputi, kunyit, jahe, serai, kayu manis, jeruk nipis, gula merah dan air. Kegiatan selanjutnya praktik pembuatan minuman sehat dengan tahapan pada Gambar 1. Pelaksanaan pembagian minuman sehat ini dilakukan pada tanggal 27 Agustus 2020, dengan jalan membagikan minuman sehat dari rempah-rempah ini kepada para pengunjung pasar, perangkat desa dan masyarakat setempat di Desa Wadeng Kecamatan Sidayu Kabupaten Gresik guna menjaga sistem imunitas tubuh.

\section{Pemanfaatan sampah plastik}

Kegiatan pemanfaatan sampah plastik menjadi perabot rumah tangga berupa kursi kecil di Desa Ngoro Mojokerto terdiri beberapa tahapan. Tahap pertama adalah pelaksanaan survei yang bertujuan untuk mendapatkan informasi lokasi-lokasi terdapatnya sampah-sampah plastik yang menumpuk di Desa Ngoro Kota Mojokerto. Tahap kedua adalah permohonan izin kepada Kepala Desa Ngoro dengan melakukan kunjungan ke Kepala desa Ngoro dengan tujuan memohon izin dan menjelaskan program kegiatan pemanfaatan sampah plastik di desa Ngoro. Hasil dari kunjungan disarankan agar pelaksanaan kegiatan dilakukan door to door ke rumah-rumah penduduk mengingat pada saat ini masih kondisi pandemi COVID-19. Pada tahap ini juga dilakukan sosialisasi terkait urgensi tidak membuang sampah sembarangan untuk menjaga kebersihan lingkungan. Tahap ketiga adalah persiapan pelaksanaan pembuatan sampah plastik menjadi kursi yang dimulai dengan persiapan alat dan bahan yang akan digunakan dalam pelatihan pembuatan kursi dari sampah plastik. 
Spices and garbage two keys to healthy life

Anis Sholihah, Yuni Aulia Agustin, Nada Kutsuma Vacha, M. Alfan Yusuf

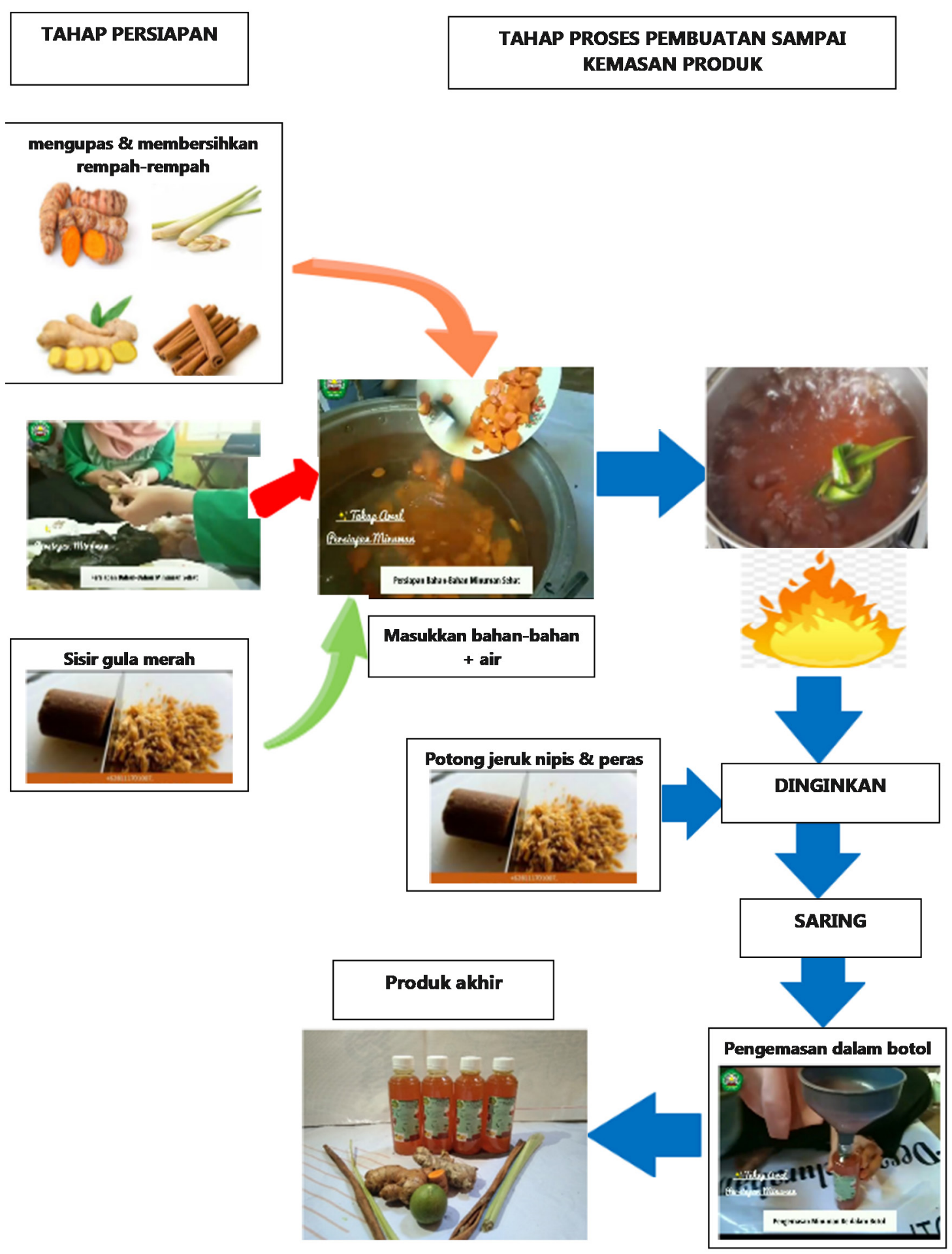

Gambar 1. Proses pembuatan minuman sehat 
ABDIMAS: Jurnal Pengabdian Masyarakat Universitas Merdeka Malang Volume 6, No. 4, November 2021: 565-574

Tahap keempat adalah pelatihan pembuatan kursi dari sampah plastik. Pelaksanaan kegiatan ini dimulai dengan sosialiasasi kepada masyarakat tentang bahaya sampah plastik dilanjutkan dengan praktik pembuatan kursi dari sampah plastik. Tahapan pembuatan kursi sebagai berikut: (1) Menyiapkan sampah plastik yang sudah dikumpulkan baik sampah plastik dalam bentuk kantong/bungkus atau botol; (2) Menggunting sampah plastik yang bentuk kantong/lembaran menjadi guntingan-guntingan kecil; (3) Memilih sampah botol plastik yang mempunyai ukuran sama karena untuk membuat kursi harus berukuran botol yang sama; (4) Memasukkan guntingan sampah yang kecil-kecil ke dalam botolbotol dan memadatkannya sampai memadat; dan (5) Botol yang sudah memadat didesain dan dirangkai menjadi kursi selanjutnya kita tambahkan cat warna agar kursi atau meja terlihat indah atau bisa juga ditambahkan kain perca dan busa agar seperti kursi spons.

\section{HASIL DAN PEMBAHASAN}

Minuman yang diolah untuk menghasilkan kegunaan bagi kesehatan di luar fungsi dasarnya dapat disebut dengan minuman fungsional. Minuman ini menyimpan berbagai zat aktif yang berkhasiat bagi kesehatan seseorang. Kekhasan sensori, baik dari segi warna maupun citarasa dan adanya komponen zat gizi serta berpengaruh baik dalam fisiologis tubuh menjadi ciri khas minuman fungsional. Efek baik dalam fisiologis tubuh manusia tersebut diantaranya adalah dapat meningkatkan imun tubuh, sebagai agen preventif penyakit dan penuaan.

Minuman fungsional banyak dibuat dari bahan baku rempah-rempah yang banyak mengandung zat bermanfaat bagi kesehatan (Batubara \& Pratiwi, 2019). Misalnya kayu manis dan kapulaga yang sudah lama digunakan untuk pewangi dan menambah cita rasa masakan (Rismunandar \& Paimin, 2009). Senyawa aktif dalam kayu manis seperti sineol, asam sinamat dan sinamaldehid memiliki peran sebagai agen antioksidan yang memberikan efek pada kesehatan (Jayaprakasha et al., 2003). Komponen bioaktif dalam kapulaga, seperti sineol, terpineol, borneol, saponin, flavonoida, dan polifenol diketahaui memiliki aktivitas serupa.

Rempah-rempah sudah menjadi unsur penting dalam kehidupan sehari-hari yang banyak memberikan efek baik dalam bidang kuliner dan medis. Tanaman rempah-rempah tersebut masih harus terus dibuktikan secara ilmiah mengingat fungsinya sebagai terapi alternatif dalam penyembuhan berbagai penyakit. Dewasa ini, perkembangan bidang pengetahuan medis berkembang pesat sehingga melahirkan berbagai jenis obat kimia yang lebih dipercaya daripada obat herbal. Manfaat obat berbasis bahan kimia dirasa memiliki efek yang lebih cepat jika dibandingkan dengan obat herbal yang diolah dengan rempah-rempah. Di samping hal tersebut, perlu diketahui bahwa obat-obatan herbal memiliki efek samping yang sangat kecil. Semakin lama, pemanfaatan herbal tidak mendapat ruang dalam masyarakat dikarenakan kepercayaan masyarakat mulai turun. Faktor yang mempengaruhi kepercayaan tersebut bisa disebabkan oleh tidak adanya lagi pengetahuan terkait menfaat dari kandungan rempahrempah sebagai obat herbal. Kondisi tersebutlah yang terjadi di Desa Wadeng Gresik, dimana hasil rempah-rempah melimpah namun masyarakat tidak optimal memanfaatkannya untuk kesehatan mereka. Oleh sebab itu, diharapkan dalam program pengabdian ini, masyarakat dapat tergugah kembali untuk memanfaatkan rempah-rempah yang berguna bagi kesehatan mereka. Sebagai insan akademik, kita 
berkewajiban untuk memanfaatkan sumber daya alam dan mengurangi konsumsi bahan-bahan kimia agar tubuh terhidar dari berbagai penyakit. Seiring berkembangnya zaman, makanan dan minuman tradisional juga mulai tergeser dengan munculnya fastfood yang banyak mengandung bahan pengawet (Trimukti et al., 2018).

Masyarakat sangat bersemangat selama kegiatan pembuatan minuman sehat. Harapannya, semoga hal ini akan berlansung terus meskipun kegiatan berakhir sehingga kearifan lokal masyarakat Indonesia tentang pengelolaan sumber daya alam tetap menjadi aset sosial budaya bangsa. Minuman sehat hasil dari kegiatan di Desa Wadeng dibagi-bagikan ke perangkat desa, pelapak dan para pembeli di Pasar Desa Wadeng dengan tujuan makin memperkenalkan produk hasil olahan dari rempah-rempah hasil bumi masyarakat sendiri. Di samping itu, kegiatan ini diharapkan dapat mengubah pola pikir masyarakat untuk terus berinovasi dalam mengolah rempah-rempah tanpa meninggalkan komposisi minuman sehat dengan tampilan dan rasa yang enak.
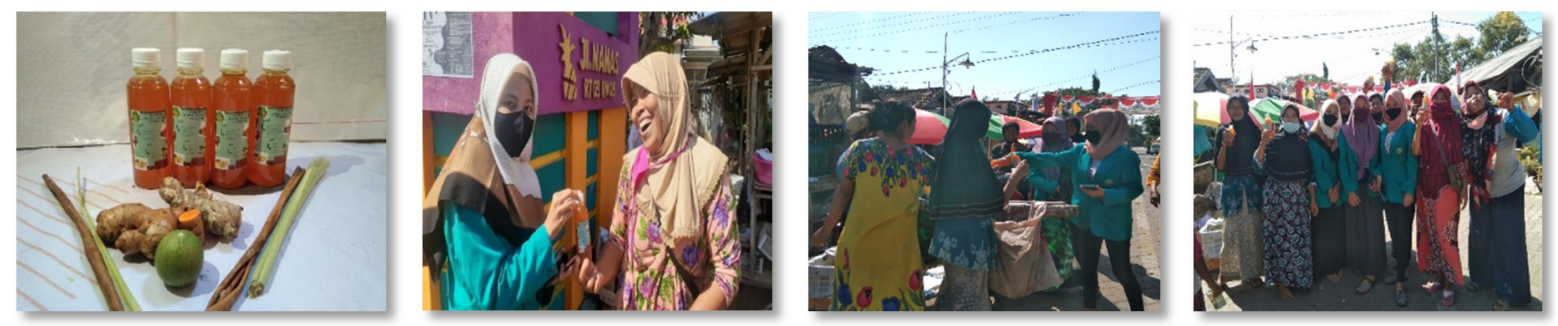

Gambar 2. Kemasan minuman sehat siap dibagikan kepada masyarakat Desa Wadeng Gambar 3. Pembagian minuman sehat kepada pelapak di Pasar Wadeng

Gambar 4. Pembagian minuman sehat kepada pengunjung pasar di Desa Wadeng

Bersamaan dengan padatnya kota dan berkembangnya teknologi dalam kehidupan masyarakat, masalah sampah masih menjadi salah satu masalah dominan dalam kaitannya dengan pencemaran lingkungan. Penanganan sampah harus dilakukan secara terstruktur dan seksama dengan menciptakan inovasi-inovasi baru. Penanganan ini dapat dilakukan dengan meninjau berbagai aspek seperti aspek sosial, ekonomi, maupun aspek teknis. Langkah ini harus segera diambil mengingat pertambahan penduduk yang akan terus naik. Keadaan ini terjadi di Desa Ngoro Gresik, dimana kuantitas sampah meningkat dari hari ke hari sejalan dengan bertambahnya penduduk. Sejauh ini, penyelesaian masalah sampah belum dapat dikatakan baik sehingga inovasi baru dibutuhkan dalam managemen pengolahan sampah, utamanya sampah plastik. Pengelolaan sampah dengan melibatkan masyarakat menjadi cara yang efektif untuk menumbuhkan kesadaran masyarakat dalam menangani masalah sampah (Nugraha et al., 2018). Hal ini terbukti dari kegiatan singkat oleh pengabdi yang menunjukkan hasil peningkatan kesadaran masyarakat dalam membuang sampah pada tempatnya (Gambar 5). Dapat terlihat bahwa terjadi penurunan yang signifikan sebesar $57 \%$ dari jumlah masyarakat yang membuang sampah sembarangan. Di sisi lain, terjadi peningkatan $61 \%$ masyarakat yang membuang sampah pada tempatnya. Managemen pengolahan sampah yang melibatkan masyarakat dinilai lebih hemat energi dan biaya serta ramah lingkungan. Selain itu, kegiatan ini dapat membantu meningkatkan taraf perekonomian masyarakat yang membuat masyarakat lebih produktif. 
ABDIMAS: Jurnal Pengabdian Masyarakat Universitas Merdeka Malang Volume 6, No. 4, November 2021: 565-574

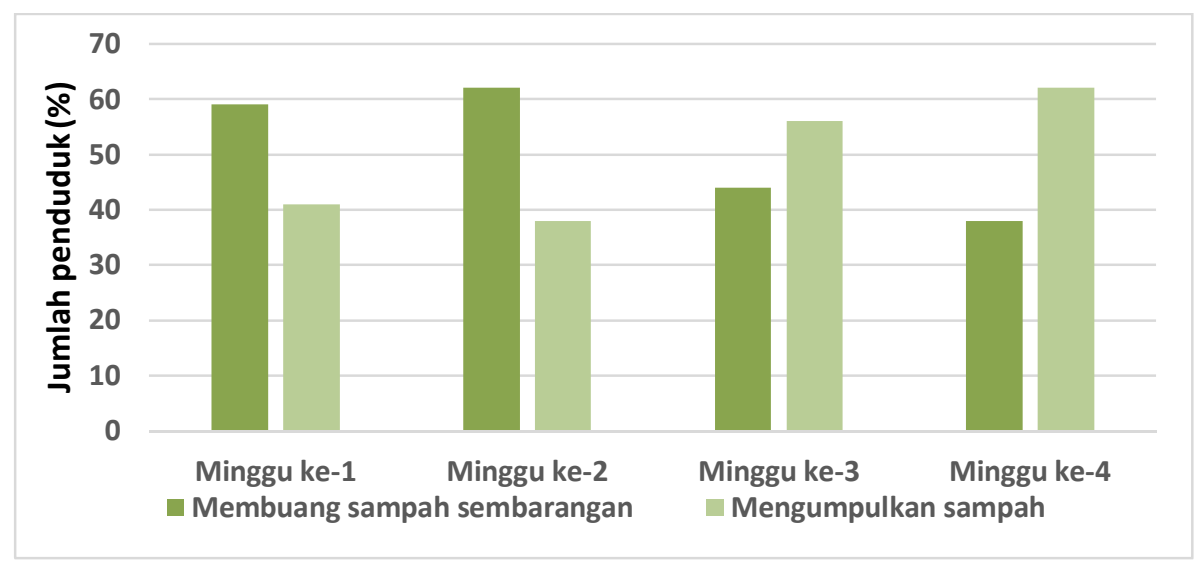

Gambar 5. Perilaku masyarakat Desa Ngoro dalam 1 bulan setelah adanya edukasi pentingnya membuang sampah pada tempatnya

Selanjutnya kegiatan pelatihan pembuatan sampah plastik menjadi kursi berjalan lancar walaupun terdapat kendala yang dihadapi mengingat kegiatan dilaksanakan pada masa pandemi sehingga pelaksanaan pelatihan dilakukan door to door ke rumah penduduk. Efektivitas waktu dan tenaga juga menjadi kendala dikarenakan volume kegiatan semakin meningkat. Hasil kegiatan ini adalah terjadi penurunan volume sampah plastik sebesar $40 \%$ - 50\% dan berubah alih fungsi menjadi barang yang lebih bermanfaat yaitu kursi kecil yang bisa digunakan sebagai perabot rumah tangga. Kendala utama yang ditemui selama kegiatan berjalan antara lain yaitu masih kurangnya partisipasi masyarakat terutama masyarakat yang berkerja sebagai buruh pabrik karena keterbatasan waktu mereka untuk mengikuti kegiatan ini. Selain itu, untuk menyadarkan masyarakat terkait urgensi pembuangan sampah pada tempatnya adalah tugas yang belum tercapai sepenuhnya.
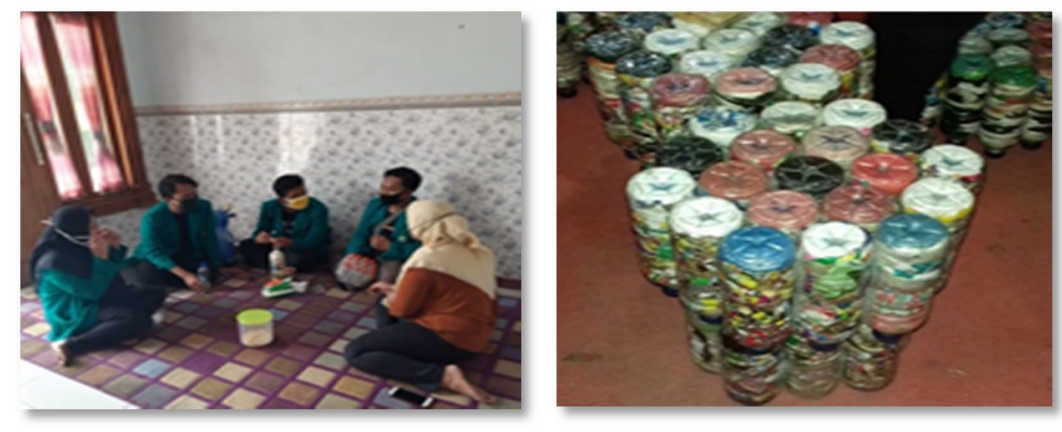

Gambar 6. Proses sosialisasi door to door di salah satu rumah warga Gambar 7. Hasil kursi dari sampah plastik

\section{SIMPULAN DAN SARAN}

Terdapatnya teknologi pembuatan minuman sehat dari rempah-rempah hasil bumi masyarakat Desa Wadeng Gresik sehingga dapat menjadi sumber alternatif pendapatan masyarakat di Desa Wadeng. 
Adapun di Desa Ngoro Mojokerto terjadi peningkatan kesadaran masyarakat sebesar $61 \%$ terkait tidak membuang sampah secara sembarangan sehingga sampah plastik dapat dimanfaatkan menjadi barang yang lebih bermanfaat yaitu kursi kecil perabot rumah tangga.

Saran untuk kegiatan di Desa Wadeng berikutnya adalah sebaiknya dilakukan pendampingan secara intens, khususnya pada penduduk yang mengolah minuman sehat sampai mendapatkan PIRT. Selanjutnya, pengolahan sampah di Desa Ngoro bisa dilanjutkan dengan pengolahan untuk menjadi pupuk kompos.

\section{Ucapan Terima Kasih}

Ucapan terima kasih ditujukan kepada Ketua LPPM Unisma, Kepala Desa Wadeng, Kepala Desa Ngoro dan serta semua warga yang mendukung dan terlibat dalam kegiatan ini.

\section{Daftar Pustaka}

Batubara, S. C., \& Pratiwi, N. A. (2019). Pengembangan minuman berbasis teh dan rempah sebagai minuman fungsional. Jurnal Industri Kreatif dan Kewirausahaan, 1(2), 27-41. https://doi. org/10.36441/kewirausahaan.v1i2.129

Duke, J. A. (2002). Handbook of Medicinal Herbs. CRC press. https://doi.org/10.1201/9781420040463

Novena, M. (2020, Desember 14). Sampah Plastik Ancam Keberadaan Hutan Mangrove Jawa. Kompas. com. https://www.kompas.com/sains/read/2020/12/14/193000723/sampah-plastik-ancamkeberadaan-hutan-mangrove-jawa

Nuraida, L., \& Hariyadi, R. D. (2001). Pangan Tradisional Basis bagi Industri Pangan Fungsional dan Suplemen. Bogor: Pusat Kajian Tradisional, Institut Pertanian Bogor

Jayaprakasha, G. K., Mohan Rao, L. J., \& Sakariah, K. K. (2003). Volatile constituents from Cinnamomum zeylanicum fruit stalks and their antioxidant activities. Journal of Agricultural and Food Chemistry, 51(15), 4344-4348. https://doi.org/10.1021/jf034169i

Nishino, J., Itoh, M., Ishinomori, T., Kubota, N., \& Uemichi, Y. (2003). Development of a catalytic cracking process for converting waste plastics to petrochemicals. Journal of Material Cycles and Waste Management, 5(2), 89-93. https://doi.org/10.1007/s10163-003-0086-6

Nugraha, A., Sutjahjo, S. H., \& Amin, A. A. (2018). Analisis persepsi dan partisipasi masyarakat terhadap pengelolaan sampah rumah tangga di Jakarta Selatan. Jurnal Pengelolaan Sumberdaya Alam dan Lingkungan (Journal of Natural Resources and Environmental Management), 8(1), 7-14.

Rismunandar, R., \& Paimin, F. B. (2009). Kayu manis budidaya dan pengolahan. Jakarta: Penebar Swadaya.

Sari, A. N. (2016). Berbagai tanaman rempah sebagai sumber antioksidan alami. Elkawnie: Journal of Islamic Science and Technology, 2(2), 203-212. http://dx.doi.org/10.22373/ekw.v2i2.2695

Badan Pusat Statistik Indonesia. (2018). Statistik Indonesia 2018. Jakarta: Badan Pusat Statistik Indonesia. 
ABDIMAS: Jurnal Pengabdian Masyarakat Universitas Merdeka Malang

Volume 6, No. 4, November 2021: 565-574

Trimukti, C. B., Putri, N. P. E. Y., Pamungkas, A. A., \& Syahrilla, R. (2018, October). Tinggalkan penyakit dengan rempah-rempah Nusantara. In Conference on Innovation and Application of Science and Technology (CIASTECH), 1(1), 18-23.

Williams, P. T., \& Slaney, E. (2007). Analysis of products from the pyrolysis and liquefaction of single plastics and waste plastic mixtures. Resources, Conservation and Recycling, 51(4), 754-769. https://doi.org/10.1016/j.resconrec.2006.12.002 